\title{
Quality and digestibility of food ingested by various trophic fish groups in the Upper Paraná River floodplain
}

\author{
Anna Christina Esper Amaro de Faria $^{1} \&$ Evanilde Benedito ${ }^{2}$ \\ 1. Parque do Ingá, Avenida São Paulo, S/N. Maringá, Paraná, Brasil. Phone: +55 (44) 9914-6640; \\ annacfaria@yahoo.com.br \\ 2. Universidade Estadual de Maringá. Avenida Colombo, 5790, Maringá, Paraná, Brasil. Phone: +55 (44) 3011-4605; \\ eva@nupelia.uem.br
}

Received 02-X-2009. Corrected 27-VII-2010. Accepted 31-VIII-2010.

\begin{abstract}
Determining quality of food ingested and digestibility can be helpful in understanding the mechanisms that determine trophic plasticity, which is the ability of a given species to use a more advantageous food source at a given time. In this study, the chemical composition and digestibility of food ingested by various trophic fish groups at different sites of the Upper River Paraná floodplain are evaluated. Specimens of Pseudoplatystoma corruscans, Prochilodus lineatus, Leporinus friderici, Pterodoras granulosus and Schizodon borellii from the Baía, Ivinheima and Paraná Rivers and from Fechada and Ventura Lagoons were taken as samples (3-16 cm-mesh net). Volume participation analyses of food items were determined and contents from the stomach and the intestine's latter quarter were removed for bromatological analysis (energy, crude protein, ash and dry matter). Internal marker acid-insoluble ash was employed for apparent digestibility coefficients. $P$. lineatus and P. corruscans had an intake with lower and higher energy and crude protein contents, respectively. $P$. corruscans had slight variations in food items and composition, whereas $P$. granulosus had the greatest variation. Whereas $P$. lineatus had the highest apparent digestibility coefficients in energy, $S$. borellii showed least variation in diet. $P$. granulosus and $P$. lineatus had the higher percentages of dry matter in the stomach in the Paraná River, whereas P. corruscans had similar use in the Baía Rivers and Ventura Lagoon. S. borellii showed low utilization of germanous energy. It may be concluded that the site determined the variation in quality and use of diet by L. friderici, P. granulosus and S. borellii. The generalist species L. friderici demonstrated a good use of different food items ingested at the site; likewise, the generalist species $P$. corruscans had a similar diet and the same use of food. Rev. Biol. Trop. 59 (1): 85-101. Epub 2011 March 01.
\end{abstract}

Key words: fish, diet, energy, nutrition, trophic levels, Paraná river.

Knowledge of fish diets, which are obtained from the analysis of stomach contents, makes it possible to evaluate the interactive processes within aquatic communities (Winemiller 1989) as well as indicate the composition of ingested items. Such knowledge does not, however, provide information on the assimilation and ratio of the sources of organic nutrients that guarantee the maintenance of these communities as components of the system (Thomas \& Cahoon 1993). As such, the caloric value and nutrient levels (Bowen et al. 1995) indicate the quality of ingested food. Additionally, determining digestibility can be helpful in understanding the mechanisms that determine trophic plasticity, which is the ability of a given species to use more advantageous food sources at a given time (Gerking 1994). Trophic plasticity depends on adaptations in the morphology of the digestive system as well as on behavior regarding capture strategies and digestive capacity (Gerking 1994, Abelha et al. 2001). Additionally, digestibility provides useful information on the ratios of high or low food utilization levels by fish. 
One of the most relevant aspects of the biological efficiency of a food source is its digestibility, which indicates the capacity of animals to digest and absorb the nutrients from a given food component (Hanley 1987), by determining the fraction of nutrient or energy of the ingested food source that is not excreted in feces (NRC 1993). These studies have revealed different availabilities of energy and protein among varied food items for different species and development stages according to food intake habits and the consequent changes in digestion physiology (Bowen et al. 1995, Degani et al. 1997).

To analyze food intake and its quality, the apparent digestibility coefficients (ADCs) are obtained for energy and macronutrients (protein, carbohydrates, lipids). The availability rates of micronutrients are also important indicators of food quality (Bowen et al. 1995, Hemre et al. 2003) because they reveal each species' capacity to utilize the food resources available in the environment.

In nutrition studies, the bromatological analysis of an ingested food item is the starting point to determine its quality. This value depends not only on the nutrient content but also on its digestibility. Among the different fish species, there is considerable variation in the ability to digest protein, which is due to the nature and specific activities of each species' proteolytic enzymes (Smith 1978). Nose (1966) reports that, in general, protein is adequately digested by most fish species, except for a few plant protein sources or in the presence of high levels of carbohydrates in the diet. Few studies have been developed in Brazil with this focus in natural environments (Yossa \& Araújo-Lima 1998, Silva et al. 2000). Some research has shown that the effective assimilation of food by fish depends also on the hydrological regime, environmental condition, water temperature, food intake, and nutrient quantity and quality, as well as the physical state of food items (Silva et al. 2000).

The ecological system of the Upper Paraná River floodplain is composed of rivers, channels, and lagoons and has proved to be complex in regards to the energy flow among its biological compartments and fish species belonging to different trophic groups (Agostinho et al. 1997). Studies discussing the digestibility of food resources by the different fish species have not yet been conducted in this system.

In this context, the objective of the present study is to determine the quality and digestibility of the diet ingested by fish belonging to different trophic groups of the Upper Paraná River floodplain, assuming that the following are true: i) individuals of the same species in different environments present various digestibility rates; ii) species with different feeding habits in the same environment present diverse diet utilization; and iii) generalist species satisfactorily use different diets.

\section{MATERIAL AND METHODS}

The study sites corresponded to the rivers Baía (RBai), Ivinheima (RIvi), Paraná (Rpar), and the lagoons Fechada (LFec) and Ventura (Lven), all belonging to the Upper Paraná River floodplain ecosystem $\left(22^{\circ} 40^{\prime}\right.$ to $22^{\circ} 50^{\prime} \mathrm{S} ; 53^{\circ}$ 10 to $53^{\circ} 40^{\prime} \mathrm{W}$ (Fig. 1).

Samplings were conducted using gillnets with mesh sizes varying between 3 and $16 \mathrm{~cm}$ between opposite knots that were set for 24 hours and thereafter checked in $8 \mathrm{~h}$ intervals (16:00h, 24:00h and 8:00h).

Quarterly field activities were conducted over six days and took place between February 2001 and February 2003, which included the rainy season and a drought period. Five fish species with different feeding habits were selected: Pseudoplatystoma corruscans (Agassiz in Spix \& Agassiz 1829) (piscivore); Schizodon borellii (Boulenger 1900) (herbivore), Prochilodus lineatus (Valenciennes 1836) (iliophagous); Leporinus friderici (Bloch 1794) and Pterodoras granulosus (Valenciennes in Humboldt \& Valenciennes 1821) (omnivores).

For diet analysis, 369 adult individuals were studied that belonged to different species and were from the same sampling site and time (Table 1). 


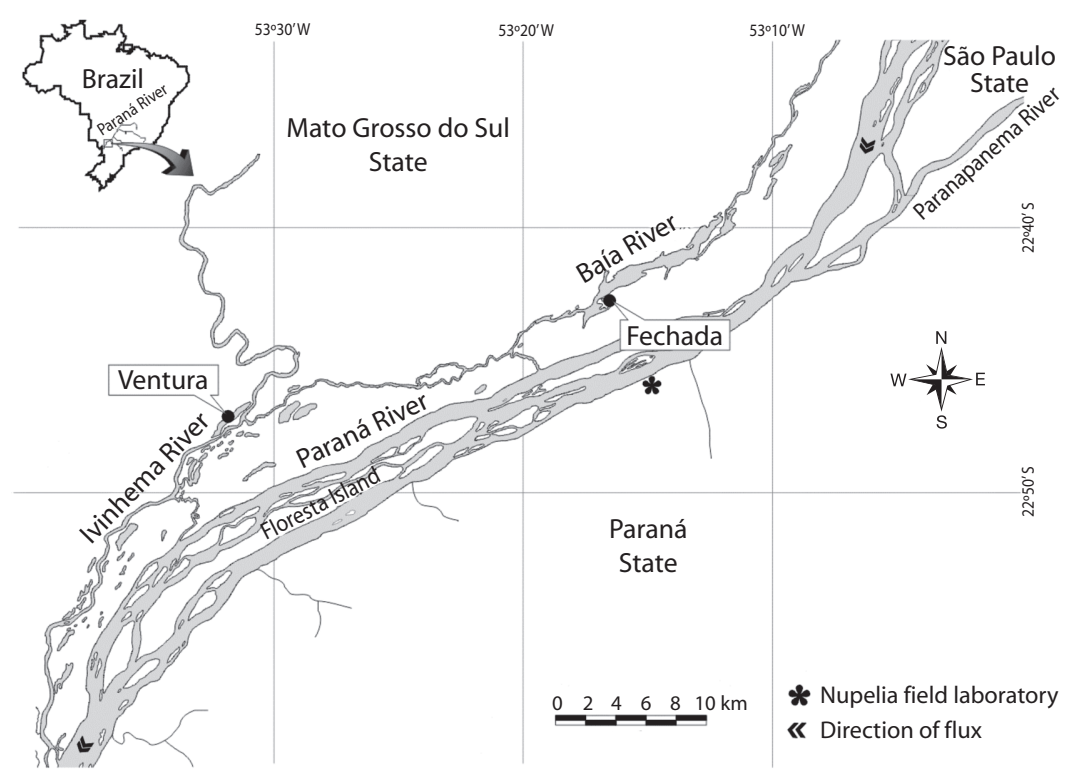

Fig. 1. Study sites corresponded to the rivers Baía (RBai), Ivinheima (RIvi), Paraná (Rpar), and the lagoons Fechada (LFec) and Ventura (Lven), all belonging to the Upper Paraná River floodplain ecosystem.

TABLE 1

Number of individuals used in the stomach analysis by sampling site and mean value and standard deviation of length standard (Ls) and total weight (Wt) of the different species analyzed in the Upper Paraná River floodplain

\begin{tabular}{lccccccc}
\multicolumn{1}{c}{ Fish species } & Ls $(\mathrm{cm})$ & Wt $(\mathrm{g})$ & LFec & LVen & RBai & RIvi & RPar \\
\hline Prochilodus lineatus & $36.4 \pm 7.2$ & $942.6 \pm 178.8$ & - & 16 & 22 & 24 & 23 \\
Leporinus friderici & $25.8 \pm 2.0$ & $297.3 \pm 80.6$ & - & - & 22 & 32 & 39 \\
Pterodoras granulosus & $50.7 \pm 6.3$ & $2594.6 \pm 482.6$ & - & 12 & 31 & 25 & 28 \\
Schizodon borelli & $24.2 \pm 3.0$ & $320.5 \pm 156.7$ & 18 & - & - & 41 & 39 \\
Pseudoplatystoma corruscans & $76.1 \pm 8.1$ & $3505.8 \pm 1087.7$ & & 8 & 7 & &
\end{tabular}

LVen=Ventura Lagoon, $\mathbf{L F e c = F e c h a d a ~ L a g o o n , ~ R B a i = B a i ́ a ~ R i v e r , ~ R I v i = I v i n h e i m a ~ R i v e r , ~ R P a r = P a r a n a ́ ~ R i v e r . ~}$

Stomach contents were removed, fixed in $4 \%$ formalin, and examined under a stereoscopic microscope; items were identified to the lowest possible taxonomic level. This analysis was conducted according to the volumetric method (Hyslop 1980) in which the volume of the items is obtained through displacement of the water column using graduated cylinders. For food items with volumes smaller than $0.1 \mathrm{ml}$, a millimetric plate was used with the volume expressed in $\mathrm{mm}^{3}$ and later converted to $\mathrm{ml}$ (Hellawel \& Abel 1971).

From each species, at least five specimens were used from each sampling site. For the analyses of the apparent digestibility coefficient, only the individuals with more than $100 \mathrm{mg}$ of material in the stomach and intestine were selected.

After measuring their standard lengths (Ls) and total weights (Wt) (Table 1), the fish 
were immediately dissected, and their digestive tracts were extracted. Stomach contents and the contents from the fourth quarter of the intestine were carefully removed so as to avoid mixing mucus with the content. After storage, the samples were kept on ice and later in a freezer $\left(-5^{\circ} \mathrm{C}\right)$ until the bromatological composition analysis.

The samples with stomach and intestinal contents were dehydrated in a forced ventilation greenhouse $\left(55^{\circ} \mathrm{C}\right)$ for $72 \mathrm{~h}$, and later ground (ball mill), refrigerated $\left(-5^{\circ} \mathrm{C}\right)$ and analyzed for dry matter, mineral matter (ash), and crude protein according to the methodology described by Silva \& Queiroz (2002). To obtain crude energy values, the samples were subjected to combustion in a calorimeter (Parr 1261) at the Energy Ecology Laboratory of the State University of Maringá (UEM), Maringá, Paraná, Brazil.

The apparent digestibility coefficients (ADC) were obtained for dry matter, mineral matter, crude energy, and crude protein through the difference between their ratios and those of the internal marker at the beginning and end of the digestive tract. Acid-insoluble ash was used as the internal marker and quantified according to the methodology proposed by Keulen \& Young (1977). To determine the ADCs of dry matter and diet nutrients, the expressions described by Maynard \& Loosly (1979) were used. $\left(\mathrm{DA}_{\mathrm{N}}\right)$ :

Apparent digestibility of diet nutrients

$$
D A_{N}=100-\left[100 *\left(\begin{array}{c}
\% I_{e} \\
\% I_{f}
\end{array}\right) \cdot\left(\begin{array}{c}
\% N_{f} \\
\% N_{e}
\end{array}\right)\right]
$$

In which $\mathrm{DA}_{\mathrm{N}}=$ apparent digestibility of the nutrient; $\% \mathrm{I}_{\mathrm{e}}$ and $\% \mathrm{I}_{\mathrm{F}=}$ percentages of indicator in the stomach and at the end of the digestive tract, respectively; $\% \mathrm{~N}_{\mathrm{e}}$ and $\% \mathrm{~N}_{\mathrm{F}=}$ percentages of nutrient in the stomach and at the end of the digestive tract, respectively.

For data analysis, the assumptions of normality (Shapiro-Wilk test) and homocedasticity
(Levene's test) were previously tested to perform the test analyses (MANOVA, ANOVA) using the computer software STASTISTICA 6.0. Tukey's t-test was applied whenever significant differences were detected between the means. The significance level assumed for all tests was $\mathrm{p}<0.05$.

\section{RESULTS}

Feeding: The volumetric frequency values for the items in the diet of Prochilodus lineatus, Leporinus friderici, Pterodoras granulosus, Schizodon borellii, and Pseudoplatystoma corruscans in the different subsystems of the Upper Paraná River floodplain are presented in Table 2. The participation of food items in the diet of $P$. lineatus was similar in all subsystems, with a predominance of sediment/detritus.

For L. friderici, a variation was observed in the prevalence of the fish, with the greatest volumetric frequency values of the food items ingested in the Baía River (RBai) followed by the Paraná (RPar) and Ivinheima (RIvi) rivers. At RBai, L. friderici consumed fewer insects compared with others systems of the Upper Paraná River Floodplain. For P. granulosus, there was a more significant consumption of bivalves (Limnoperma fortunei and Corbicula fluminea) and other mollusks and lower consumption of plants at RPar, as compared to LVen and RIvi. The results of stomach content analysis of S. borellii and P. corruscans determined there was a predominance of plants and fish, respectively, in all subsystems where these species were sampled. However, S. borellii presented differences in ingested items, with the predominance of macrophytes at LFec and RPar and gramineae at RIvi. At RPar, conversely, there was an unusual and noteworthy consumption of fruits and seeds in the stomachs of S. borellii.

\section{Chemical composition and diet digestibility:}

a) Interspecific comparisons: Caloric content values and crude protein levels in the 


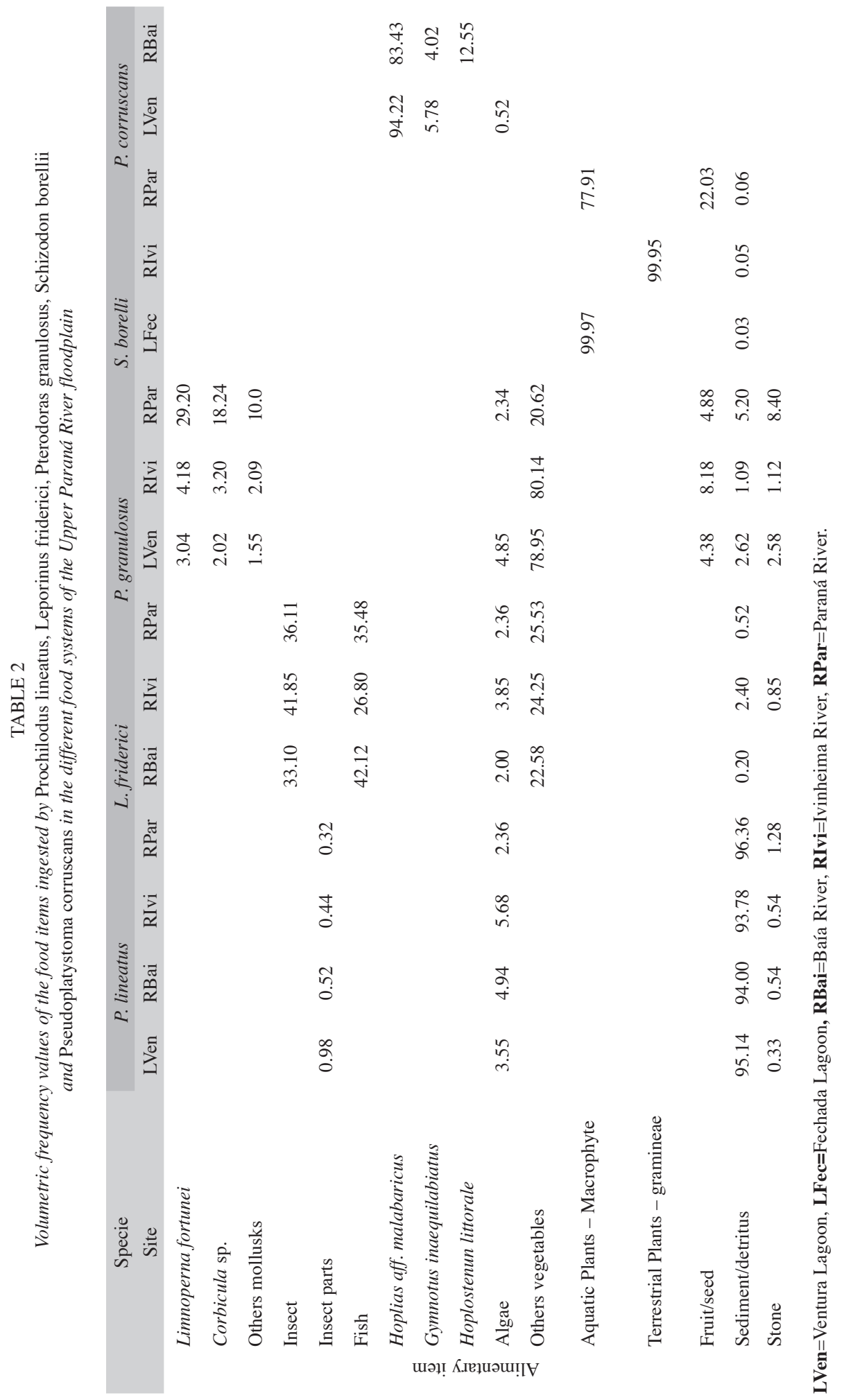


food items ingested by different species and the digestibility coefficients (ADC) of food items (Fig. 2 and Table 3) (MANOVA, $\mathrm{F}_{16,294}=39.18$, $\mathrm{p}<0.01)$ showed that the food ingested by $P$. lineatus had lower energy levels (ANOVA, $\left.\mathrm{F}_{4,99}=39.18, \mathrm{p}<0.01\right)$ than the other species (Tukey, $\mathrm{p}<0.001$ ) and lower protein levels (ANOVA, $\mathrm{F}_{4,99}=90.47, \mathrm{p}>0.01$ ) in comparison with $P$. corruscans and $P$. granulosus (Tukey, $\mathrm{p}>0.01$ ). Conversely, $P$ corruscans had the highest levels of energy and protein (Tukey, $\mathrm{p}<0.001)$. The diet of $L$. friderici had energy values similar to those of $P$. granulosus and $S$. borellii, whereas the protein level was similar only to that of $S$. borellii (Tukey, $\mathrm{p}>0.05$ ) and was lower than that of $P$. granulosus (Tukey, $\mathrm{p}<0.001)$.
The results of ADC analysis showed P. lineatus had better food utilization rates (ANOVA, $\left.\mathrm{F}_{4,99}=37.918, \mathrm{p}=0.0001\right)$ than $P$. corruscans, $P$. granulosus and S. borellii (Tukey, $\mathrm{p}=0.0003$; 0.0045 and 0.0011 , respectively) and similar rates to L. friderici (Tukey, p>0.05) (Fig. 2 and Table 4). On the other hand, the protein ADC (ANOVA, $\mathrm{F}_{4,99}=30.047, \mathrm{p}<0.001$ ) for this species was higher than those of $L$. friderici and $S$. borellii (Tukey, $\mathrm{p}<0.001$ ) yet similar to P. granulosus and P. corruscans ( $\mathrm{p}>0.05$ ). Schizodon borellii had the lowest energy and protein utilization levels (Tukey, $\mathrm{p}<0.001$ ) of all other species. The ADC values of $L$. friderici were similar for energy when compared to $P$. granulosus and P. corruscans (Tukey, $\mathrm{p}=0.6105$ and 0.0699 , respectively); however,
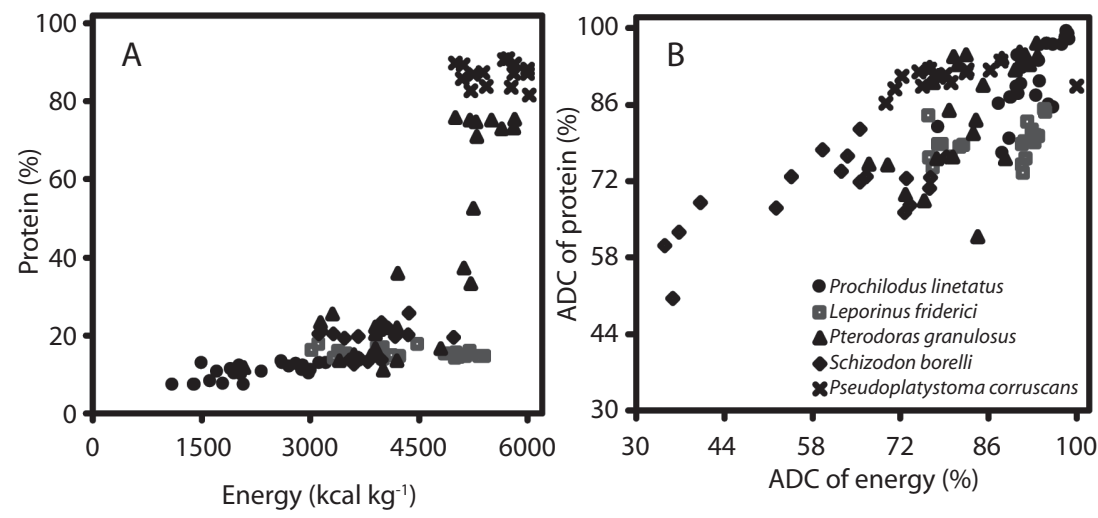

Fig. 2. Protein and energy values (A) of ingested diet and apparent digestibility coefficients (ADC) of crude protein and energy. (B) For five fish species of the Upper Paraná River floodplain.

TABLE 3

Mean energy and protein values in the ingested food items and apparent digestibility coefficients (ADC) of the diet of five fish species of the Upper Paraná River floodplain ${ }^{1}$

\begin{tabular}{lcccc} 
& \multicolumn{2}{c}{ Food in stomach } & \multicolumn{2}{c}{ CDA $(\%)$} \\
Specie & Energy $(\mathrm{kcal} / \mathrm{kg})$ & Protein $(\%)$ & Energy & Protein \\
P. lineatus & $2253.21 \pm 133.28 \mathrm{c}$ & $10.61 \pm 0.44 \mathrm{c}$ & $92.83 \pm 1.01 \mathrm{a}$ & $90.53 \pm 1.33 \mathrm{a}$ \\
L. friderici & $4266.30 \pm 171.32 \mathrm{~b}$ & $15.43 \pm 0.25 \mathrm{c}$ & $87.48 \pm 1.57 \mathrm{ab}$ & $79.07 \pm 0.70 \mathrm{~b}$ \\
P. granulosus & $4360.14 \pm 193.32 \mathrm{~b}$ & $37.51 \pm 4.98 \mathrm{~b}$ & $83.82 \pm 1.46 \mathrm{~b}$ & $86.19 \pm 1.98 \mathrm{a}$ \\
S. borellii & $3885.95 \pm 103.96 \mathrm{~b}$ & $18.55 \pm 0.92 \mathrm{c}$ & $60.54 \pm 3.54 \mathrm{c}$ & $70.08 \pm 1.70 \mathrm{c}$ \\
P. corruscans & $5554.21 \pm 92.55 \mathrm{a}$ & $86.97 \pm 0.76 \mathrm{a}$ & $79.59 \pm 1.98 \mathrm{~b}$ & $90.93 \pm 0.49 \mathrm{a}$
\end{tabular}

${ }^{1}$ Values in the same column followed by the same letter do not differ significantly by Tukey's test (p>0.05). 
TABLE 4

Mean values for bromatological composition of stomach and intestine contents of five fish species from the Upper Paraná River floodplain ${ }^{1}$

\begin{tabular}{|c|c|c|c|c|c|c|c|c|}
\hline \multirow{2}{*}{ Local } & \multicolumn{2}{|c|}{ Energy (kcal/kg) } & \multicolumn{2}{|c|}{ Protein $(\%)$} & \multicolumn{2}{|c|}{ Ash $(\%)$} & \multicolumn{2}{|c|}{ Dry matter $(\%)$} \\
\hline & Stomach & Intestine & Stomach & Intestine & Stomach & Intestine & Stomach & Intestine \\
\hline \multicolumn{9}{|c|}{ Prochilodus lineatus } \\
\hline LVen & $\begin{array}{c}2851.52 \\
\pm 240.45 \mathrm{a}\end{array}$ & $\begin{array}{c}1044.68 \\
\pm 221.21 \mathrm{a}\end{array}$ & $\begin{array}{c}11.27 \\
\pm 0.52 \mathrm{a}\end{array}$ & $\begin{array}{c}4.89 \\
\pm 0.32 \mathrm{a}\end{array}$ & $\begin{array}{c}43.86 \\
\pm 1.66 \mathrm{a}\end{array}$ & $\begin{array}{c}70.23 \\
\pm 7.27 \mathrm{a}\end{array}$ & $\begin{array}{c}88.92 \\
\pm 1.47 \mathrm{a}\end{array}$ & $\begin{array}{c}89.13 \\
\pm 3.69 \mathrm{ab}\end{array}$ \\
\hline RBai & $\begin{array}{c}1932.58 \\
\pm 117.33 \mathrm{~b}\end{array}$ & $\begin{array}{c}458.01 \\
\pm 52.16 \mathrm{~b}\end{array}$ & $\begin{array}{c}10.71 \\
\pm 0.47 \mathrm{a}\end{array}$ & $\begin{array}{c}4.30 \\
\pm 0.44 \mathrm{a}\end{array}$ & $\begin{array}{c}46.83 \\
\pm 0.84 \mathrm{a}\end{array}$ & $\begin{array}{c}74.09 \\
\pm 5.43 \mathrm{a}\end{array}$ & $\begin{array}{c}89.51 \\
\pm 1.48 \mathrm{a}\end{array}$ & $\begin{array}{c}91.86 \\
\pm 1.27 \mathrm{a}\end{array}$ \\
\hline RIvi & $\begin{array}{l}2758.55 \\
\pm 52.44 \mathrm{a}\end{array}$ & $\begin{array}{l}869.37 \\
28.21 \mathrm{a}\end{array}$ & $\begin{array}{c}11.91 \\
\pm 0.33 \mathrm{a}\end{array}$ & $\begin{array}{c}4.47 \\
\pm 0.88 \mathrm{a}\end{array}$ & $\begin{array}{c}47.81 \\
\pm 1.66 \mathrm{a}\end{array}$ & $\begin{array}{c}67.33 \\
\pm 2.82 \mathrm{a}\end{array}$ & $\begin{array}{c}93.11 \\
\pm 1.32 \mathrm{a}\end{array}$ & $\begin{array}{c}83.43 \\
\pm 4.07 \mathrm{ab}\end{array}$ \\
\hline RPar & $\begin{array}{c}1569.91 \\
\pm 140.98 \mathrm{~b}\end{array}$ & $\begin{array}{c}116.62 \\
\pm 24.75 \mathrm{~b}\end{array}$ & $\begin{array}{c}7.25 \\
\pm 0.14 \mathrm{~b}\end{array}$ & $\begin{array}{c}0.56 \\
\pm 0.11 \mathrm{~b}\end{array}$ & $\begin{array}{c}45.01 \\
\pm 3.47 \mathrm{a}\end{array}$ & $\begin{array}{c}69.61 \\
\pm 2.90 \mathrm{a}\end{array}$ & $\begin{array}{c}93.37 \\
\pm 1.41 \mathrm{a}\end{array}$ & $\begin{array}{c}78.60 \\
\pm 1.57 \mathrm{~b}\end{array}$ \\
\hline \multicolumn{9}{|c|}{ Leporinus friderici } \\
\hline RBai & $\begin{array}{c}3687.14 \\
\pm 177.82 \mathrm{~b}\end{array}$ & $\begin{array}{c}808.01 \\
\pm 19.92 \mathrm{~b}\end{array}$ & $\begin{array}{c}15.67 \\
\pm 0.51 \mathrm{a}\end{array}$ & $\begin{array}{c}10.21 \\
\pm 0.15 \mathrm{a}\end{array}$ & $\begin{array}{c}38.06 \\
\pm 1.98 \mathrm{a}\end{array}$ & $\begin{array}{c}60.09 \\
\pm 5.21 \mathrm{a}\end{array}$ & $\begin{array}{c}88.87 \\
\pm 1.12 \mathrm{a}\end{array}$ & $\begin{array}{c}89.03 \\
\pm 2.52 \mathrm{a}\end{array}$ \\
\hline RIvi & $\begin{array}{c}3946.17 \\
\pm 224.61 \mathrm{~b}\end{array}$ & $\begin{array}{c}1541.22 \\
\pm 536.14 \mathrm{~b}\end{array}$ & $\begin{array}{c}14.66 \\
\pm 0.28 \mathrm{ab}\end{array}$ & $\begin{array}{c}10.41 \\
\pm 0.22 \mathrm{a}\end{array}$ & $\begin{array}{c}39.00 \\
\pm 3.25 \mathrm{a}\end{array}$ & $\begin{array}{c}58.73 \\
\pm 5.51 \mathrm{a}\end{array}$ & $\begin{array}{c}90.17 \\
\pm 1.12 \mathrm{a}\end{array}$ & $\begin{array}{c}90.67 \mathrm{a} \\
\pm 1.64\end{array}$ \\
\hline RPar & $\begin{array}{c}5165.58 \\
\pm 60.71 \mathrm{a}\end{array}$ & $\begin{array}{c}3464.22 \\
\pm 134.11 \mathrm{a}\end{array}$ & $\begin{array}{c}14.35 \\
\pm 0.25 \mathrm{~b}\end{array}$ & $\begin{array}{c}10.43 \\
\pm 0.17 \mathrm{a}\end{array}$ & $\begin{array}{c}18.89 \\
\pm 2.29 \mathrm{~b}\end{array}$ & $\begin{array}{c}46.50 \\
\pm 4.70 \mathrm{a}\end{array}$ & $\begin{array}{c}88.32 \\
\pm 2.02 \mathrm{a}\end{array}$ & $\begin{array}{c}89.69 \\
\pm 1.83 \mathrm{a}\end{array}$ \\
\hline \multicolumn{9}{|c|}{ Pterodoras granulosus } \\
\hline LVen & $\begin{array}{c}4033.03 \\
\pm 383.30 \mathrm{~b}\end{array}$ & $\begin{array}{c}2802.15 \\
\pm 310.16 \mathrm{a}\end{array}$ & $\begin{array}{c}27.69 \\
\pm 3.98 \mathrm{~b}\end{array}$ & $\begin{array}{c}10.10 \\
\pm 2.11 \mathrm{a}\end{array}$ & $\begin{array}{c}7.45 \\
\pm 0.64 \mathrm{~b}\end{array}$ & $\begin{array}{c}23.02 \\
\pm 2.58 \mathrm{~b}\end{array}$ & $\begin{array}{l}93.35 \mathrm{a} \\
\pm 1.13 \mathrm{a}\end{array}$ & $\begin{array}{c}90.97 \\
\pm 2.39 \mathrm{~b}\end{array}$ \\
\hline RIvi & $\begin{array}{c}3785.91 \\
\pm 122.13 \mathrm{~b}\end{array}$ & $\begin{array}{c}3033.43 \\
\pm 234.90 \mathrm{a}\end{array}$ & $\begin{array}{c}15.55 \\
\pm 1.23 \mathrm{c}\end{array}$ & $\begin{array}{c}14.00 \\
\pm 1.04 \mathrm{a}\end{array}$ & $\begin{array}{c}6.12 \\
\pm 0.32 \mathrm{~b}\end{array}$ & $\begin{array}{c}14.77 \\
\pm 1.75 \mathrm{~b}\end{array}$ & $\begin{array}{c}94.03 \\
\pm 1.02 \mathrm{a}\end{array}$ & $\begin{array}{c}93.08 \\
\pm 1.27 \mathrm{~b}\end{array}$ \\
\hline RPar & $\begin{array}{c}5445.94 \\
\pm 105.43 \mathrm{a}\end{array}$ & $\begin{array}{r}1420.32 \\
\pm 82.31 \mathrm{~b}\end{array}$ & $\begin{array}{c}71.62 \\
\pm 0.56 \mathrm{a}\end{array}$ & $\begin{array}{c}12.38 \\
\pm 0.53 \mathrm{a}\end{array}$ & $\begin{array}{c}22.40 \\
\pm 1.21 \mathrm{a}\end{array}$ & $\begin{array}{c}56.98 \\
\pm 4.27 \mathrm{a}\end{array}$ & $\begin{array}{c}91.95 \\
\pm 1.50 \mathrm{a}\end{array}$ & $\begin{array}{c}76.73 \\
\pm 1.82 \mathrm{a}\end{array}$ \\
\hline \multicolumn{9}{|c|}{ Schizodon borellii } \\
\hline LFec & $\begin{array}{l}4177.63 \\
\pm 67.14 \mathrm{a}\end{array}$ & $\begin{array}{c}3379.42 \\
\pm 192.94 \mathrm{a}\end{array}$ & $\begin{array}{c}21.09 \\
\pm 0.91 \mathrm{a}\end{array}$ & $\begin{array}{c}11.29 \\
\pm 0.25 \mathrm{a}\end{array}$ & $\begin{array}{c}18.36 \\
\pm 4.93 \mathrm{a}\end{array}$ & $\begin{array}{c}58.44 \\
\pm 8.86 \mathrm{a}\end{array}$ & $\begin{array}{c}91.63 \\
\pm 0.96 \mathrm{a}\end{array}$ & $\begin{array}{c}90.33 \\
\pm 2.55 \mathrm{a}\end{array}$ \\
\hline RIvi & $\begin{array}{c}3769.76 \\
\pm 275.23 \mathrm{a}\end{array}$ & $\begin{array}{c}3410.09 \\
\pm 364.65 \mathrm{a}\end{array}$ & $\begin{array}{c}19.49 \\
\pm 0.39 \mathrm{a}\end{array}$ & $\begin{array}{c}10.90 \\
\pm 0.17 \mathrm{a}\end{array}$ & $\begin{array}{c}16.20 \\
\pm 1.39 \mathrm{a}\end{array}$ & $\begin{array}{c}45.16 \\
\pm 4.04 \mathrm{a}\end{array}$ & $\begin{array}{c}91.28 \\
\pm 1.01 \mathrm{a}\end{array}$ & $\begin{array}{c}88.53 \\
\pm 2.29 \mathrm{a}\end{array}$ \\
\hline RPar & $\begin{array}{c}3710.47 \\
\pm 64.05 \mathrm{a}\end{array}$ & $\begin{array}{r}1180.24 \\
\pm 35.86 \mathrm{~b}\end{array}$ & $\begin{array}{c}13.15 \\
\pm 0.23 \mathrm{~b}\end{array}$ & $\begin{array}{c}4.90 \\
\pm 0.10 \mathrm{~b}\end{array}$ & $\begin{array}{c}13.30 \\
\pm 1.37 \mathrm{a}\end{array}$ & $\begin{array}{c}44.78 \\
\pm 5.00 \mathrm{a}\end{array}$ & $\begin{array}{c}86.37 \\
\pm 1.34 \mathrm{~b}\end{array}$ & $\begin{array}{c}88.98 \\
\pm 2.03 \mathrm{a}\end{array}$ \\
\hline \multicolumn{9}{|c|}{ Pseudoplatystoma corruscans } \\
\hline LVen & $\begin{array}{c}5538.08 \\
\pm 143.21 \mathrm{a}\end{array}$ & $\begin{array}{c}3746.29 \\
\pm 151.22 \mathrm{a}\end{array}$ & $\begin{array}{c}84.69 \\
\pm 0.96 \text { a }\end{array}$ & $\begin{array}{c}26.35 \\
\pm 0.87 \mathrm{a}\end{array}$ & $\begin{array}{c}46.57 \\
\pm 1.58 \mathrm{a}\end{array}$ & $\begin{array}{c}64.58 \\
\pm 4.17 \mathrm{a}\end{array}$ & $\begin{array}{c}87.38 \\
\pm 1.70 \mathrm{a}\end{array}$ & $\begin{array}{c}86.59 \\
\pm 2.25 \mathrm{a}\end{array}$ \\
\hline RBai & $\begin{array}{c}5568.33 \\
\pm 129.13 \mathrm{a}\end{array}$ & $\begin{array}{c}3824.14 \\
\pm 257.48 \mathrm{a}\end{array}$ & $\begin{array}{c}82.88 \\
\pm 1.22 \mathrm{a}\end{array}$ & $\begin{array}{c}21.71 \\
\pm 1.12 \mathrm{~b}\end{array}$ & $\begin{array}{c}48.13 \\
\pm 1.50 \mathrm{a}\end{array}$ & $\begin{array}{c}65.69 \\
\pm 3.48 \mathrm{a}\end{array}$ & $\begin{array}{c}89.47 \\
\pm 1.56 \mathrm{a}\end{array}$ & $\begin{array}{c}82.47 \\
\pm 3.83 \mathrm{a}\end{array}$ \\
\hline
\end{tabular}

LVen=Ventura Lagoon, $\mathbf{L F e c = F e c h a d a ~ L a g o o n , ~ R B a i = B a i ́ a ~ R i v e r , ~ R I v i = I v i n h e i m a ~ R i v e r , ~ R P a r = P a r a n a ́ ~ R i v e r . ~}$

${ }^{1}$ Values regarding the same fish in the same column followed by the same letter do not differ significantly by the Tukey test $(p>0.05)$ or ANOVA $(p>0.05)$. 
the protein ADCs for L. friderici were lower than those of of $P$. granulosus (Tukey, $\mathrm{p}<0.05$ ) and P. corruscans (Tukey, $\mathrm{p}<0.001$ ). Pterodoras granulosus and $P$. corruscans had similar energy utilization (Tukey, $\mathrm{p}>0.05$ ) and protein levels (Tukey, $\mathrm{p}>0.05$ ).

b) Spatial comparisons: The study observed an effect of the site on the chemical composition (energy, crude protein, mineral matter, and dry matter) and digestibility coefficients (ADC) of the diet for P. lineatus (MANOVA, $\mathrm{F}_{36,24,365}=5.1558, \mathrm{p}=0.0004$ ), $P$. granulosus, (MANOVA, $\mathrm{F}_{24,26}=17.335$, $\mathrm{p}=0.0001), \quad$ L. friderici (MANOVA, $\mathrm{F}_{24}$ ${ }_{14}=5.100, \mathrm{p}=0.001$ ), and $S$. borellii (MANOVA, $\left.\mathrm{F}_{24,8}=39.164, \mathrm{p}=0.00001\right)$. For $P$. corruscans, however, an effect was observed only for protein content in the intestine (MANOVA, $\mathrm{F}_{12}$, ${ }_{2}=0.87095, \mathrm{p}=0.65027$ ).

Prochilodus lineatus: The energy content of food in the stomach (ANOV, $\mathrm{F}_{3}$, $\left.{ }_{19}=18.989, \mathrm{p}=0.00001\right)$ and intestine of this species (ANOVA, $\mathrm{F}_{3,19}=16.927, \mathrm{p}=0.00001$ ) was higher for specimens sampled at LVen in comparison with those from RBai (Tukey, $\mathrm{p}<0.001$ ) and RPar (Tukey, $\mathrm{p}<0.05$ ). However, these levels did not differ from those observed for RIvi (Tukey, $\mathrm{p}>0.0001$ ) (Table 4).

The percentages of crude protein in the stomach (ANOVA, $\mathrm{F}_{3,19}=30.779, \mathrm{p}=0.000001$ ) and intestine (ANOVA, $\mathrm{F}_{3,19}=14.207$, $\mathrm{p}=0.00004$ ) were greater at RIvi than at RPar (Tukey, $\mathrm{p}=0.00181$ and $\mathrm{p}=0.0004$, respectively). These values, however, did not differ from the values observed at LVen (Tukey, $\mathrm{p}=0.656264$ and $\mathrm{p}=0.9502$, respectively) and RBai (Tukey, $\mathrm{p}=0.136501$ and $\mathrm{p}=0.9950$, respectively). The levels of crude protein at LVen in the stomach (Tukey, $\mathrm{p}=0.00182$ ) and intestine (Tukey, $\mathrm{p}=0.0003$ ) and at RBai in the stomach (Tukey, $\mathrm{p}=0.0019$ ) and intestine (Tukey, $\mathrm{p}=0.0006$ ) were also greater than those obtained at RPar but did not differ among themselves (Tukey, $\mathrm{p}=0.741662$ and $\mathrm{p}=0.870485$, respectively).

There was no difference between the values for mineral matter in the stomachs (ANOVA,
$\left.\mathrm{F}_{3,19}=0.64019, \mathrm{p}=0.59847\right)$ and intestines (ANOVA, $\mathrm{F}_{3,19}=0.37043, \mathrm{p}=0.77522$ ) as well as in dry matter in the stomachs of the individuals sampled at the different sites. However, a greater level of dry matter was observed in the intestine at RBai (ANOVA, $\mathrm{F}_{3,19}=4.4096$, $\mathrm{p}<0.05$ ) compared to at RPar (Tukey, $\mathrm{p}<0.05$ ), although no differences were observed among the other averages (Table 4).

Leporinus friderici: For this species, the energy contents of the stomach (ANOVA, $\mathrm{F}_{2,18}=0.0001$ ) and intestine (ANOVA, $\mathrm{F}_{2}$, $\left.{ }_{18}=18.459, \mathrm{p}=0.0004\right)$ were higher at RPar (Tukey, $\mathrm{p}<0.001$ ) when compared to RBai. The mean obtained at RPar for both the stomach (Tukey, $\mathrm{p}<0.001$ ) and the intestine (Tukey, $\mathrm{p}=0.00142$ ) was higher than at RIvi (Tukey, $\mathrm{p}<0.001)$. No differences were observed betweeb RBai and Rivi values in either portion of the digestive tract (Tukey, $\mathrm{p}=0.053624$ and $\mathrm{p}=0.0261651$, respectively) (Table 4).

The level of crude protein in the stomach (ANOVA, $\mathrm{F}_{2,18}=3.5951, \mathrm{p}=0.04857$ ) was higher at RBai in comparison to RPar (Tukey, $\mathrm{p}=0.0490$ ). The values at both RBai (Tukey, $\mathrm{p}=0.150367$ ) and RPar (Tukey, $\mathrm{p}=0.821744$ ) did not differ from those for RIvi with no significant differences in the intestine (ANOVA, $\mathrm{F}_{2,18}=0.45712, \mathrm{p}=0.64026$ ) among crude protein levels for this species, regardless of sampling site.

Pterodoras granulosus: The energy value of stomach contents (ANOVA, $\mathrm{F}_{2,24}=13.099$; $\mathrm{p}<0.01)$ was higher at RPar in relation to RIvi (Tukey, $\mathrm{p}<0.001$ ); in the intestine, (ANOVA, $\mathrm{F}_{2,24}=12.693, \mathrm{p}=0.00017$ ) the energy value was higher at RIvi than at RPar (Tukey, $\mathrm{p}<0.001$ ) (Table 4).

The level of crude protein in the stomach (ANOVA, $\mathrm{F}_{2,24}=138.73$, $\mathrm{p}<0.01$ ) was different in all environments (Tukey, $\mathrm{p}<0.01$ ); however, no differences were observed among the values of these nutrients (ANOVA, $\mathrm{F}_{2,24}=2.0149$, $\mathrm{p}=0.15527$ ) in the intestines of fish from the different sites. 
The levels of ash in the stomach (ANOVA, $\left.\mathrm{F}_{2,24}=137.44, \mathrm{p}=0.000001\right)$ and the intestine (ANOVA, $\mathrm{F}_{2,24}=57.957, \mathrm{p}=0.000001$ ) of fish from RPar were higher than those from RIvi (Tukey, p<0.001). At Lven, the obtained values did not differ from the stomach (Tukey, $\mathrm{p}>0.05$ ) and intestine (Tukey, $\mathrm{p}>0.05$ ) values for fish from RIvi and Rpar. These were, however, different values from those obtained at RPar for the stomach (Tukey, $\mathrm{p}<0.001$ ) and intestine (Tukey, $\mathrm{p}<0.001$ ).

There was no effect of the subsystems on the means obtained for dry matter in the stomach (ANOVA, $\mathrm{F}_{2,24}=075.915, \mathrm{p}=0.47898$ ). However, intestinal levels of individuals from LVen and RIvi did not differ (Tukey, $\mathrm{p}>0.05$ ) but were higher than those observed for RPar (Tukey, $\mathrm{p}<0.001$ ).

Schizodon borellii: The results of the ANOVA obtained for $S$. borellii indicated that there were no differences in the stomach energy contents $\left(\mathrm{F}_{2,15}=2.3003, \mathrm{p}=0.13449\right)$, ash in the stomach $\left(\mathrm{F}_{2,15}=0.68770, \mathrm{p}=0.5179\right)$, ash in the intestine $\left(\mathrm{F}_{2,15}=1.5158, \mathrm{p}=0.25144\right)$, and dry matter in the intestine $\left(\mathrm{F}_{2,15}=0.16542\right.$, $\mathrm{p}=0.84906$ ) as a result of the subsystems. However, differences were found in the intestine energy contents $\left(F_{2,15}=28.6020, p=0.00001\right)$ with higher values at RPar than at LFec (Tukey, $\mathrm{p}<0.001$ ) and RIvi (Tukey, $\mathrm{p}<0.001$ ); however, the latter two sites had similar means (Tukey, $\mathrm{p}=0.9956$ ) (Table 4).

In regards to the levels of crude protein in the stomach (ANOVA, $\mathrm{F}_{2,15}=51.678$, $\mathrm{p}=0.0001$ ) and intestine (ANOVA, $\mathrm{F}_{2}$, $\left.{ }_{15}=375.44, \mathrm{p}=0.000001\right)$, observed mean values were lower at RPar in relation to LFec (Tukey, $\mathrm{p}<0.001$ ) and RIvi (Tukey, $\mathrm{p}<0.001$ ); however, there was no difference between values in the stomach (Tukey, $\mathrm{p}=0.163479$ ) and intestine (Tukey, $\mathrm{p}=0.3293$ ) at LFec and RIvi.

For dry matter level in the stomach, differences were observed (ANOVA, $\mathrm{F}_{2,15}=6.9641$, $\mathrm{p}=0.00726$ ) with lower values at RPar than at LFec (Tukey, p<0.05) and RIvi (Tukey, $\mathrm{p}<0.05)$ (Table 4).
There was an effect of the subsystems for ash values in the stomach (ANOVA, $\mathrm{F}_{2}$, ${ }_{18}=19.585, \mathrm{p}=0.00003$ ) with similar mean values for RIvi and RBai (Tukey, $\mathrm{p}=0.964032$ ), which were higher than at RPar (Tukey, $\mathrm{p}<0.001$ ). There were no differences in ash values in the intestine (ANOVA, $\mathrm{F}_{2,18}=2.1134, \mathrm{p}=0.14982$ ) or in dry matter percentages in the stomach (ANOVA, $\mathrm{F}_{3,19}=4.4096, \mathrm{p}=0.01628$ ) and intestine (ANOVA, $\mathrm{F}_{2,18}=0.16413, \mathrm{p}=0.84988$ ).

Pseudoplatystoma corruscans: No differences were observed in the mean values of subsystems LVen and RBai for energy contents in the stomach $\left(\mathrm{F}_{1,13}=0.2473, \mathrm{p}=0.8775\right)$ and intestine $(\mathrm{F}=0.6295, \mathrm{p}=0.80582)$, protein levels in the stomach $(\mathrm{F}=1.3081, \mathrm{p}=0.27336)$, ash in the stomach $(\mathrm{F}=0.51517, \mathrm{p}=0.48561)$ and intestine $(\mathrm{F}=0.04274, \mathrm{p}=0.83941)$, and dry matter in the stomach $(\mathrm{F}=0.82332, \mathrm{p}=0.38072)$ and intestine $(\mathrm{F}=0.79658, \mathrm{p}=0.38839)$. However, protein levels in the intestine at LVen were higher $(\mathrm{F}=10.258, \mathrm{p}=0.00693)$ than those at Rbai (Table 4).

Diet digestibility: Energy (Fig. 3A): In regards to the Apparent Digestibility Coefficients (ADC) of energy (ANOVA, $\mathrm{F}_{3}$, $\left.{ }_{19}=8.6852, \mathrm{p}<0.01\right)$ (Fig. 3A) for P. lineatus, the values obtained at RPar were higher than at RIvi (Tukey, $\mathrm{p}=0.0114$ ) and LVen (Tukey, $\mathrm{p}=0.006$ ) but did not differ from those observed for RBai (Tukey, $\mathrm{p}=0.0903$ ). The ADC for this species at LVen did not differ from those found at RIvi (Tukey, $\mathrm{p}=0.4210$ ) and RBai (Tukey, $\mathrm{p}=0.0881$ ). No differences were observed (Tukey, $\mathrm{p}=0.7482$ ) between the values for RBai and RIvi.

For P. granulosus, the energy ADC at RPar (ANOVA, $\mathrm{F}_{2,24}=15.413, \mathrm{p}<0.01$ ) was higher than at LVen (Tukey, $\mathrm{p}<0.01$ ) and RIvi (Tukey, $\mathrm{p}<0.01)$. However, there was no difference between the values at LVen and RIvi (Tukey, $\mathrm{p}=0.277615$ ). For L. friderici (ANOVA, $\mathrm{F}_{2}$, ${ }_{18}=32.405, \mathrm{p}<0.01$ ), a lower ADC value was observed at RPar than at RBai and RIvi (Tukey, $\mathrm{p}<0.01$ ), but the values for RBai and RIvi were similar to one another (Tukey, $\mathrm{p}=0.173612$ ). 

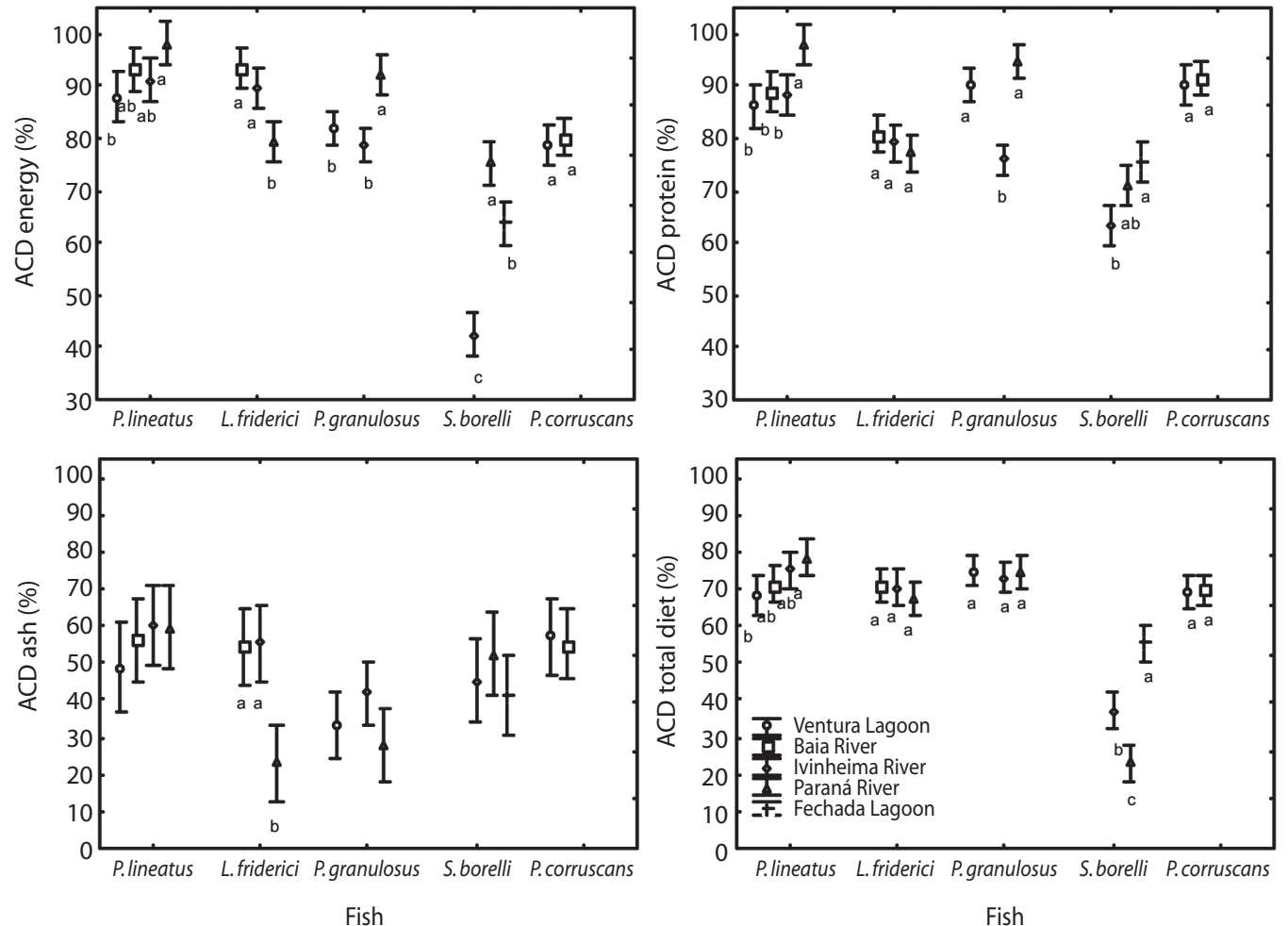

Fig. 3. Means and standard deviation (bars) of the apparent digestibility coefficients (ADC) of energy, crude protein, mineral matter, and total food consumed by five species in different subsystems of the Upper Paraná River floodplain ${ }^{1}$.

${ }^{1}$ Values regarding the same fish in the same column followed by the same letter do not differ significantly by the Tukey test $(\mathrm{p}>0.05)$ or ANOVA $(\mathrm{p}>0.05)$.

The energy ADCs of the diet of $S$. borellii (ANOVA, $\mathrm{F}_{2,15}=55.040, \mathrm{p}<0.01$ ) were different in all subsystems with higher values at RPar than at LFec (Tukey, p<0.01) and RIvi (Tukey, $\mathrm{p}<0.01$ ), whereas the values observed at RIvi were lower (Tukey, $\mathrm{p}<0.01$ ) than those for LFec. For P. corruscans, the energy ADCs at RBai and LVen were similar (ANOVA, $\mathrm{F}_{12}$, ${ }_{2}=0.87095$, $\mathrm{p}=0.65027$ ).

Protein (Fig. 3B): The crude energy ADC for P. lineatus (ANOVA, $\mathrm{F}_{3,19}=7.2201$, $\mathrm{p}=0.00199$ ) was higher at RPar than at LVen (Tukey, $\mathrm{p}<0.01$ ), RBai (Tukey, $\mathrm{p}<0.05$ ) and RIvi (Tukey, $\mathrm{p}<0.05$ ). However, the values at RBai were similar to those at LVen (Tukey, $\mathrm{p}=0.756804$ ) and RIvi (Tukey, $\mathrm{p}=0.9973$ ). The latter two subsystems featured values that did not differ from one another (Tukey, $\mathrm{p}=0.8597$ ).

For L. friderici, there was no difference in the crude protein ADCs (ANOVA, $\left.\mathrm{F}_{2,18}=3.2318, \mathrm{p}=0.06321\right)$ in the subsystems. For $P$. granulosus (ANOVA, $\mathrm{F}_{2,24}=18.823$, $\mathrm{p}<0.01)$, RPar and LVen had similar values (Tukey, $\mathrm{p}=0.365568$ ), which were higher than those observed at RIvi (Tukey, $\mathrm{p}<0.01$ ). The digestibility of this nutrient for $S$. borellii (ANOVA, $\mathrm{F}_{2,15}=7.7988, \mathrm{p}<0.01$ ) was greater at $\mathrm{LFec}$ than at RIvi (Tukey, $\mathrm{p}<0.01$ ); however, both environments had values that did not differ from those obtained at RPar (Tukey, $\mathrm{p}=0.313759$ and $\mathrm{p}=0.071818$, respectively). The protein ADCs at LVen and RBai for P. cor- 
ruscans (ANOVA, $\mathrm{F}_{1,13}=0.24448, \mathrm{p}=0.62924$ ) were statistically similar.

Ash (mineral matter) (Fig. 3C): The ANOVA of the mineral matter ADC for $P$. lineatus $\left(\mathrm{F}_{3,19}=1.0578 ; \mathrm{p}=0.3902\right)$, $\mathrm{P}$. granulosus $\left(\mathrm{F}_{2,24}=1.1296, \mathrm{p}=0.33975\right)$, S. borellii $\left(\mathrm{F}_{2}\right.$, $\left.{ }_{15}=2.015, \mathrm{p}=0.16785\right)$, and $P$. corruscans $\left(\mathrm{F}_{1}\right.$, ${ }_{13}=0.23525, \mathrm{p}=0.63573$ ) were not affected by the different sites. However, for L. friderici (ANOVA, $\mathrm{F}_{2,18}=29.086, \mathrm{p}=0.0001$ ), a lower ADC was observed at RPar than at RBai and RIvi (Tukey, $p<0.001$ ), whereas the values for RBai and RIvi did not differ from one another (Tukey, $\mathrm{p}=0.9730$ ).

Total diet (Fig. 3D): No effects of the subsystems were observed on the total diet ADCs for L. friderici (ANOVA, $\mathrm{F}_{2,18}=1.5897$, $\mathrm{p}=0.23132$ ) and for $P$. granulosus (ANOVA, $\mathrm{F}_{2}$, $\left.{ }_{24}=0.25180, \mathrm{p}=0.77943\right)$. For $P$. lineatus individuals (ANOVA, $\mathrm{F}_{3,19}=4.4653, \mathrm{p}=0.01554$ ), the total diet digestibility at RPar did not differ from RBai (Tukey, $\mathrm{p}=0.01097$ ) and RIvi (Tukey, $\mathrm{p}=0.7079$ ) but was higher than that at LVen (Tukey, $\mathrm{p}=0.0145$ ). The values for LVen did not differ from those for RBai (Tukey, $\mathrm{p}=0.6878$ ) and RIvi (Tukey, $\mathrm{p}=0.1154$ ). The total diet digestibility at RBai was similar to that for RIvi (Tukey, $\mathrm{p}=0.5554$ ).

The total diet ADC for $S$. borellii (ANOVA, $\left.\mathrm{F}_{2,15}=17.501, \mathrm{p}>0.001\right)$ at $\mathrm{LFec}$ was higher than at RIvi and RPar (Tukey, $\mathrm{p}=0.0116$ and $\mathrm{p}<0.001$, respectively). However, the values at RIvi and RPar did not differ from one another (Tukey, $\mathrm{p}>0.05$ ). No differences were found between the total diet digestibility at RPar and LVen (ANOVA, $\mathrm{F}_{1,13}=0.02424, \mathrm{p}=0.87866$ ) for $P$. corruscans individuals.

\section{DISCUSSION}

Prochilodus lineatus: In spite of having the ingested food with the lowest energy and protein contents, $P$. lineatus had elevated Apparent Digestibility Coefficients (ADC) for both measurements, which indicates that this species possesses a digestive system that is able to efficiently use a nutritionally poor food source (Bowen et al. 1995). Another strategy that allows such efficiency is the ability to ingest large quantities of food in relation to body weight (Yossa \& Araújo-Lima 1998). The fact that there were discrepancies in energy, protein, and ADC contents for P. lineatus may be related to the quantity of ingested food because the diet of $P$. lineatus is mainly composed of detritus and sediment (Table 1) (Hahn et al. 2002). Although the energy levels at Rpar were higher than at LVen and RIvi, the higher total diet ADCs of both at the site indicates that the diet was composed of more digestible items for that species.

The food energy values at Rpar and values of crude protein (7.25 to $11.27 \%$ ) in the food consumed by $P$. lineatus in this study are similar to those found by Bowen et al. (1984), with 7.3 to $18.3 \%$ in the detritus ingested by Prochilodus platensis in the Mid Paraná, Río de la Plata, Argentina, and slightly higher than that found for P. nigricans by Yossa \& AraújoLima (1998).

Total diet and protein ADCs found for $P$. lineatus in this study for all environments are higher than those reported by Yossa \& AraújoLima (1998) for Prochilodus nigricans and Liposarcus pardalis in lagoons of the Central Amazon floodplain and by Bowen (1981) for Tilapia mossambica consuming periphyton attached to the detritus. Yossa (2002) reported low food digestibility of Curimatidae and Prochilodontidae from the Amazon basin, which indicates that the food items consumed by Prochilodus in the Paraná River basin are more digestible.

Although $P$. lineatus had similar intake habits in the different subsystems, the levels of energy, protein, and ash in the stomach varied according to site, especially for the data from Rpar and Lven. These differences are probably due to the variations in organism participation in the decomposition chain, such as algae, bacteria and fungi, which were not observed in the stomach content analysis due to the high level of decomposition. 
The high level of ash (43 to 47\%) observed in the food ingested by P. lineatus is in accordance with reports for other detrivorous species, which have diets comprised of between 10 and $70 \%$ organic matter (Bowen 1984, Araújo-Lima \& Hardy 1987). However, Yossa \& Araújo-Lima (1998) observed lower values for $P$. nigricans than those values for $P$. lineatus in this study. This elevated participation of mineral matter in the food ingested by $P$. lineatus is justified by the strategy of food collection by detrivorous fish species.

Leporinus friderici: Although differences were identified for protein levels and consumed items in the different subsystems, protein ADCs did not differ, which indicates that this species equally utilizes protein from different sources, such as fish and insects, which demonstrates its omnivorous eating habits (Hahn et al. 1997, Hahn et al. 1998; Balassa et al. 2004) and opportunist behaviors (Balassa et al. 2004). The higher energy value and lower energy ADC at RPar reflects a difference in the chemical composition of the ingested food item, which is reinforced by the lower level of mineral matter in the diet of fish from RPar. Thus, even though this fish presented the same feeding habit in the different environments, there was an intake of higher energy items (animal or plant) at RPar. The protein levels verified for the diet ingested by $L$. friderici were slightly below those observed for Colossoma macropomum during the flood period (11 to $15 \%$ ) by Silva et al. (2000) when fruits and plants are the basis of this species' diet.

The satisfactory utilization of food by $L$. friderici with varying chemical compositions among the subsystems may enable feeding plasticity, which occurs in this species and a few others in the floodplain due to the ecosystem diversity and the hydrologic regime, which cause seasonal variation in food availability (Hahn et al. 2002, Marçal-Simabuku \& Peret, 2002). Cyrino (1984) and Oliveira-Filho \& Fracalossi (2006) also did not observe differences in the utilization of animal or vegetal protein for Brycon cephalus and Rhamdia quelen, respectively, both of which are omnivores. However, Borghetti et al. (1991) report that Piaractus mesopotamicus requires part of its diet (23\%) to be of animal origin, although it features high ADCs for energy and protein for food from animal and plant sources (Abimorad \& Carneiro 2004), whereas Meer et al. (1995) and Faria et al. (2001) highlight that Colossoma macropomum and Leporinus macrocephalus, respectively, utilize vegetal protein more favorably than other species.

Pterodoras granulosus: The food items consumed by $P$. granulosus had the highest variation in composition, in terms of ingested items, caloric values, and levels of protein and ash in the subsystems. The higher levels of protein and ash found at RPar are due to the greater participation of bivalves in the food ingested in that environment. This greater capacity to utilize food energy and protein at RPar indicates that this fish, although it displays great diet plasticity, also better utilizes animal prey, such as bivalves. This result supports studies by Silva et al. (2005). These authors affirm that $P$. granulosus is able to utilize soft tissues from both $C$. fluminea and L. fortunei without damaging their shells. The possibility that C. fluminea represents up to $90 \%$ of the diet was reported by Gaspar da Luz et al. (2002). As such, although this species is considered omnivorous in the Upper Paraná River floodplain (Hahn et al. 1992, Hahn et al. 1998; Gaspar da Luz et al. 2002) with a diet that reflects the abundance of feeding resources in the different environments of that plain (Cantanhêde et al. 2006) with a strong tendency towards herbivory (Hahn et al. 1992), the results indicate the species makes better use of an animal-based diet in the absence of plant-based sources. This was also demonstrated through stable isotope analysis, given its trophic position, which occupied the third trophic level (Faria 2007).

A variation in the composition of the ingested diet, similar to that observed in this work for P. granulosus, was reported by Silva et al. (2000) for Colossoma macropomum. They noted that this species' energy and 
protein levels markedly increased from season to season due to zooplankton intake, varying between $11 \%$ and $57 \%$ of protein and 484.6 to $574.2 \mathrm{kcal} / \mathrm{g}$ in the drought and flood seasons, respectively.

The better utilization of animal-based protein by $P$. granulosus differed from that observed by Meer et al. (1995) for C. macropomum, which are species considered to be omnivorous with a strong herbivore tendency. These authors affirmed that individuals from this species make better use of plant-based protein.

During dissection of the final portion of the digestive tract of $P$. granulosus, it was observed that $C$. fluminea shells were intact (without their inner content). This low digestibility of the shell is due to the fact it is composed basically of calcium, a nutrient that is required in low quantities for fish (approximately $1 \%$, NRC 1993) and is therefore poorly absorbed in high levels, as in the diet of $P$. granulosus at Rpar.

The fact that $P$. granulosus has better digestibility of animal-based food items may be related to the enzymatic activity of this species and the composition of vegetal tissues. According to Gerking (1994), the digestion level of food items varies according to their origin, and vegetal-based sources are less digested than animal-based items for most fish. This is because the cellular wall hinders the penetration and action of digestive enzymes. Thus, compounds such as cellulose and lignin reduce the digestibility of ingested food items.

Schizodon borellii: The variation in the participation of ingested items at the different sites, as indicated by the stomach content analysis of S. borellii, was confirmed by the results of the bromatological composition. Thus, at the sites where more plants (macrophytes or gramineae) were consumed, the levels of protein were similar.

The different energy ADCs for S. borellii in the different environments was influenced by a better utilization of food items containing macrophytes and fruits. At RPar, this is due to the fact that fruit and seed tissues are more digestible than structural tissue (Bowen et al. 1995); some Brazilian fish species have better utilization of seeds and grains than of fish meal (Faria et al. 2001, Silva et al. 2003). It is important to emphasize that the energy and protein digestibility of gramineae (RIvi) was lower than that of macrophytes ( $\mathrm{LFec}$ ), which indicates higher availability of these nutrients in macrophytes. Even so, S. borellii is a strictly herbivorous species (Hahn et al. 2002) and it had variations in diet utilization; this difference is due to fact that Gramineae have more support tissue, which results in lower energy content (Bowen et al. 1995). The caloric content utilization of Gramineae (RIvi) by S. borellii was similar to that obtained by Buddington (1979) for Najas guadalupensis ingested by Tilapia zilli $(45.4 \%)$, whereas macrophytes (Lfec) presented higher energy digestibility.

Total diet ADCs, which recorded only plants (RIvi and Lfec), were lower than those found for cichlid Etroplus suratensis fed with Hydrilla verticellata (50-51.9\%) by De Silva \& Perera (1983), Tilapia nilotica fed with Cyanophyta $(43 \%)$ by Moriarty \& Moriarty (1973) and Stegaster nigricans fed with Enteromorpha algae $(75 \%)$ by Galetto \& Bellwood (1994). On the other hand, they were higher than those values reported by Buddington (1979) for T. zilli feeding on Najas guadalupensis $(29.3 \%)$. Protein digestibility at RIvi (Gramineae) was similar to that obtained by De Silva \& Perera (1983) feeding H. verticellata to E. suratensis (65.6\%). However, at LVen (macrophytes), protein utilization by $S$. borellii was higher than those reported in this study.

Protein digestibility of macrophytes ( $\mathrm{LFec})$ in this study was similar to that found in Najas guadalupensis for T. zilli (75.1\%) by Buddington (1979) and for the algae Enteromorpha for S. nigricans by Galetto \& Bellwood (1994).

Pseudoplatystoma corruscans: Pseudoplatystoma corruscans ingested mainly fish, which resulted in a small variation in ingested items, with individuals at RBai featuring a small reduction in the participation of Hoplias 
malabaricus and the occurrence of Hoplosternum littorale. At RBai, there were no oscillations in food quality (bromatological composition) or in digestibility, and ADCs remained high (about $70 \%$ of ACD total diet). This is due to the fact that $P$. corruscans is a specialist species and therefore has few diet alterations (Bowen 1983, Gerking 1994, Hahn et al. 2002).

With the objective of determining the digestibility coefficient for $P$. corruscans in an experimental essay, Gonçalves \& Carneiro (2003) found values of $84.1 \%$ for protein and $72.8 \%$ for energy when fish were fed with fish meal and lower values when fed with plantbased protein-rich items. In the present study, the energy and protein ADC values for P. corruscans are higher than those reported by the aforementioned authors. These differences are possibly due to the fact that fish meal contains residue from processing (Faria et al. 2001) and therefore has higher levels of ash, which reduces food digestibility.

The present study made it possible to verify the existence of a wide range in the composition of ingested food items, especially in regards to energy contents and protein levels by the different species. In some cases, as in that for $P$. granulosus, variations were found in the diet ingested by the same species at different sites. In general, these variations agree with those described by Bowen et al. (1995). Thus, the lowest caloric values and crude protein levels occurred in the food items ingested by the detrivorous species ( $P$. lineatus), followed by the herbivores ( $S$. borellii) and omnivorous species (L. friderici and P. granulosus), with the highest energy and protein values obtained in the diet of $P$. corruscans (piscivore).

The occurrence of ash absorption by all species analyzed in this study and also reported by Bowen (1981) for T. mossambica, as well as the difference in their ADCs for L. friderici, contributes to the hypothesis that, although it is used as an indicator in several fish studies (Getachew 1988), ash may not represent the best indicator for digestibility studies in natural environments for the species in this report. In this study, acid-insoluble ash was used as the internal marker, which according to Buddington (1980), Bowen (1981) Galetto \& Bellwood (1994), Yossa \& Araújo-Lima (1998) and Vidal et al. (2004), constitutes a good indicator in fish digestibility studies because it is not affected by the digestion process and is not assimilated.

Deforestation, overfishing, stocking of exotic species, pollution, and construction of dams have changed, and overfishing has drastically changed, the main ecosystems, both in relation to stocks and biodiversity (Barbarino-Duque et al. 1998). The Paraná River Basin, the second largest in South America, suffers from the many dams that constrict the movement of stocks of the commercial fish species examined in this study (Okada et al. 2005). The only free stretch of the basin, the floodplain of the Paraná River, has guaranteed suitable ecological conditions for breeding, feeding, and growth to sustain the stocks exploited in the downstream, the Itaipu Reservoir, where the community depends on the riverside commercial fishing, (artisanal, and subsistence fisheries). Therefore, it is important to remove the old practices (pollution, stocking) and maintain the forest on the banks of major rivers that form the basin. The present study provides evidence for conservation of the natural environment, and further investigations are needed to understand the influence of seasons and physiological characteristics of the species (sex and maturity stage) so that fish managers can better inform themselves for the drafting of legislation that will be more appropriate both for fishing and for the protection of biodiversity. Determining food digestibility in a natural environment may provide guidelines for conservation and management practice of commercially important fish stocks in the Upper Paraná River floodplain, in addition to providing valuable information on ecological aspects of the different fish species. This knowledge could also be used in aquaculture to determine feeding management and the formulation of rations. 


\section{ACKNOWLEDGMENTS}

To the Graduate Program in Continental Aquatic Environments of the State University of Maringá (PEA-UEM); to Capes for financial support; to the field teams of the PELD LongTerm Ecological Project (UEM-NUPELIA) for their help in collecting biological materials; to the Limnology laboratory of Research Nucleus in Limnology, Ichthyology and Aquaculture (NUPELIA) and the Animal Science Department (Food Analysis laboratory) for giving access to equipment; to Sara Rodrigues, for assisting in the analysis; to Célia de Almeida Lopes and Gislaine Iachstel Manetta for the suggestions; to Marcelo Dalpasquale for the English version of this manuscript.

\section{RESUMEN}

Determining quality of food ingested and digestibility can be helpful in understanding the mechanisms that determine trophic plasticity, which is the ability of a given species to use a more advantageous food source at a given time). El objetivo de este estudio fue evaluar la composición química y la digestibilidad de los alimentos consumidos por los peces de los diferentes grupos tróficos en diferentes lugares de la llanura de inundación del alto río Paraná. Fueron colectados (red 3 a $16 \mathrm{~cm}$ de tela) individuos de Pseudoplatystoma corruscans, Prochilodus lineatus, Leporinus friderici, Pterodoras granulosus y Schizodon borellii en los ríos Baía (Rbai) Ivinheima (RIvi) y Paraná (RPar), lagunas Fechado (LFec) y Ventura (LVen). Se realizaron análisis de la participación en volumen de elementos alimentarios como contenido estomacal y el contenido de la cuarta parte final del intestino fue removido para análisis bromatológicos (energía, proteína, cenizas y materia seca). Se determinaron los coeficientes de digestibilidad aparente (CDA) utilizando las cenizas insolubles en ácido como marcador interno. $P$. lineatus y $P$. corruscans consumieron alimentos con menores y mayores contenidos de energía y proteína bruta, respectivamente con $P$. corruscans teniendo poca variación en los elementos y en la composición del alimento, mientras que PG presentó la mayor variación de estos. P. lineatus tuvo mejores CDA de la energía y $S$. borellii presentó la menor utilización de energía alimentaria. $P$. granulosus y $P$. lineatus tuvieron un mejor uso del alimento en el RPar y $P$. corruscans presentó aprovechamiento similar en el RBai y Lven. Schizodon borellii tuvo bajo aprovechamiento de la energía proveniente de las gramíneas. Se concluye que $L$. friderici, $P$. granulosus e $S$. borellii presentaron variación en la calidad y en el aprovechamiento del alimento consumido debido a los subsistemas. El L. friderici, especie generalista, presen- tó buena utilización de los diferentes alimentos consumidos en los subsistemas, mientras que $P$. corruscans, especialista, tenía una dieta similar y el mismo aprovechamiento.

Palabras clave: peces, dieta, energía, nutrición, niveles tróficos, Río Paraná.

\section{REFERENCES}

Abelha, M.C.F., A.A. Agostinho \& E. Goulart. 2001. Plasticidade trófica em peixes de água doce. Acta Sci. Biol. Sci. 23: 425-434.

Abimorad, E. \& D.J. Carneiro. 2004. Métodos de coleta de fezes e determinação dos coeficientes de digestibilidade da fração protéica e da energia de alimentos para o pacu, Piaractus mesopotamicus (Holmberg, 1887). Rev. Bras. Zootec. 33: 1101-1109.

Agostinho, A.A., N.S. Hahn, L.C. Gomes \& L.M. Bini. 1997. Estrutura Trófica, p. 229-248. In A.E.A.A.M. Vazoller, A.A. Agostinho \& N.S. Hahn (eds.). A planície de inundação do rio Paraná: aspectos físicos, biológicos e socioeconômicos. EDUEM/NUPELIA, Maringá, Paraná, Brasil.

Araújo-Lima, C.A.R.M. \& E. Hardy. 1987. Aspectos biológicos de peixes amazônicos. VIII. A alimentação dos alevinos de jaraqui (Semaprochilodus insignis). Amazoniana 10: 127-136.

Balassa, G.C., R. Fugi, N.S. Hahn \& A.B. Galina. 2004. Dieta de espécies de Anostomidae (Teleostei, Characiformes) na área de influencia do reservatório de Manso, Mato Grosso, Brasil. Iheringia 94: 77-82.

Barbarino-Duque, A., D.C. Taphorn \& K.O. Winemiller. 1998. Ecology of the coporo, Prochilodus mariae (Characiformes, Prochilodontidae), and status of annual migrations in western Venezuela. Environmental Biology of Fishes. 53: 33-46.

Borghetti, J.R., E.M. Lepeleire \& D.R. Fernandez. 1991. Os efeitos da origem da proteína no crescimento do pacu (Piaractus mesopotamicus) criado em tanques rede. Rev. Bras. Biol. 51: 689-694.

Bowen, S.H. 1981. Digestion and Assimilation of periphytic detrital Agregate by Tilapia mossambica. Am. Fish. Soc. 110: 239-245.

Bowen, S.H. 1983. Detritivory in neotropical fish communities. Environ. Biol. Fish. 9: 137-144.

Bowen, S.H. 1984. Detritivory in neotropical fish communities, p. 59-66. In T.M. Zaret (ed.). Evolutionary ecology of neotropical freshwater fish. Dr. W. Junk, The Hague, Netherland. 
Bowen, S.H., A.A. Bonetto \& M.O. Ahlgren. 1984. Microorganisms and detritus in the diet of a typical neotropical riverine detritivore, Prochilodus platensis (Pisces: Prochilodontidae). Limnol. Oceanogr. 29: $1120-1122$

Bowen, S.H., E.V. Lutz \& M.O. Ahlgren. 1995. Dietary protein and energy as determinants of food quality: Trophic strategies compared. Ecol. 76: 899-907.

Buddington, R.K. 1979. Digestion of an aquatic macrophyte by Tilapia zilli (gervis). J. Fish. Biol. 15: 449-455.

Buddington, R.K. 1980. Hydrolysis-resistant organic matter as a reference for measurement of fish digestive efficiency. Trans. Am. Fish. Soc. 109: 653-656.

Cantanhêde, G., N.S. Hahn, E.G. Gubiani \& R. Fugi. 2006. Invasive molluscs in the diet of Pterodoras granulosus (Valenciennes, 1821) (Pisces, Doradidae) in the Upper Paraná River floodplain, Brazil. Ecol. Fresh. Fish 17: 47-53.

Cyrino, J.E.P. 1984. Digestibilidade da proteína de origem animal e vegetal pelo matrinxã Brycon cephalus Günter, 1869 (Euteleostei, Characoidei, Characidae). Master Thesis, Fundação Universidade do Amazonas - INPA, Manaus, Brasil.

De Silva, S.S. \& M.K. Perera. 1983. Digestibility of aquatic macrophyte by the cichid Etroplus suratensis (Bloch) with observations on the relative merits of three indigenous components as markers and daily changes in protein digestibility. J. Fish Biol. 23: 675-684.

Degani, G., S. Viola \& Y. Yehuda. 1997. Apparent digestibility of protein and carbohidrate in feed ingredients for adult tilapia (Oreochromis aureus x Oreochromis niloticus). Isr. J. Aquac. 49: 115-123.

Faria, A.C.E.A. 2007. Fontes de energia, posição trófica e digestibilidade de peixes de diferentes níveis tróficos da planície de inundação do alto rio Paraná. Ph.D. Thesis, Universidade Estadual de Maringá, Maringá, Brasil.

Faria, A.C.E.A., C. Hayashi \& C.M. Soares. 2001. Substituição parcial e total da farinha de peixe pelo farelo de soja em dietas para alevinos de piavuçu, Leporinus macrocephalus (Garavello and Britski, 1988). Acta Scientia 23: 835-840.

Galetto, M.J. \& D.R. Bellwood. 1994. Digestion of algae by Stegastes nigricans and Amphiprion akindynos (Pisces: Pomacentridae), with an evaluation of methods used in digestibility studies. J. Fish Biol. 44: 415-428
Gaspar Da Luz, K.D., R. Fugi, F. Abujanra, A.A. Agostinho \& L.C. Gomes. 2002. Alterations in the Pterodoras granulosus (Valenciennes, 1983) (Osteichthyes, Doradidae) diet due to the abundance variation of a bivalve invader species in the Itaipu REservoir, Brazil. Acta Sci. Biol. Sci. 24: 427-432.

Gerking, S.D. 1994. Feeding ecology of fish. Academic Press, San Diego, USA.

Getachew, T. 1988. Digestive efficiency and nutrient composition gradient in the gut of Orechromis niloticus L. in Lake Awasa, Ethiopia. J. Fish Biol. 33: 501-509.

Gonçalves, E.G. \& D.J. Carneiro. 2003. Coeficientes de digestibilidade aparente da proteína e energia para alguns ingredientes utilizados em dietas para o Pintado (Pseudoplatystoma corruscans). Rev. Bras. Zootec. 32: 779-786.

Hahn, N.S., A. Monfredinho Jr., R. Fugi \& A.A. Agostinho. 1992. Aspectos da alimentação do armado, Pterodoras granulosus (Ostariophysi, Doradidae) em distintos ambientes do Alto rio Paraná. Rev. UNIMAR 14: 163-176.

Hahn, N.S., I.F. Andrian, R. Fugi \& V.L.L. Almeida. 1997. Ecologia trófica, p. 209-228. In A.E.A.M. Vazzoler, A.A. Agostinho \& N.S. Hahn (eds.). A planície de inundação do alto rio Paraná: aspectos físicos, biológicos e sócio-econômicos. EDUEM/NUPELIA, Maringá, Paraná, Brasil.

Hahn, N.S., A.A. Agostinho, L.C. Gomes \& L.M. Bini. 1998. Estrutura trófica da ictiofauna do reservatório de Itaipu (Paraná-Brasil) nos primeiros anos de sua formação. Interciência 23: 299-305.

Hahn, N.S., R. Fugi, D. Peretti, M.R. Russo \& V.E.C. Loureiro. 2002. Estrutura Trófica da Ictiofauna da Planície de Inundação do Alto rio Paraná, p 131-135. In A.A. Agostinho, S.M. Thomaz, L. Rodrigues \& L.C. Gomes. A Planície de Inundação do Alto rio Paraná. Universidade Estadual De Maringá. NupeliaPELD-CNP, Maringá, Brasil.

Hanley, F. 1987. The digestibility of foodstuffs and the effects of feeding selectivity determinations in Tilapia (Oreochromis niloticus L). Aquac. Res. 66: 163-179.

Helawel, J.M. \& R. Abel. 1971. A rapid volumetric method for the analysis of the food of fishes. J. Fish Biol. 3: 29-37.

Hemre, G.I., O. Karlsen, A. Mangor-Jensen \& G. Rosenlund. 2003. Digestibility of dry matter, protein, starch and lipid by cod, Gadus morhua: comparison of sampling methods. Aquaculture 225: 225-232. 
Hyslop, E.J. 1980. Stomach contents analysis, a review of methods and their application. J. Fish Biol. 17: 411-429.

Keulen, V. \& B.A. Young. 1977. Evaluation of acid-insoluble ash as natural marker in ruminant digestibility studies. J. Anim. Sc. 44: 238-287.

Marçal-Simabuku, M.A. \& A.C. Peret. 2002. Alimentação de peixes (Osteichthyes, Characiformes) em duas lagoas de uma planície de inundação brasileira da bacia do rio Paraná. Interciência 27: 299-306.

Maynard, L.A. \& J.K. Loosly. 1979. Animal nutrition. McGraw-Hill, New York, USA.

Meer, M.B., M.A.M. Machiels \& M.C.J. Verdegem. 1995. The effect of dietary protein level on growth, protein utilization and body composition of Colossoma macropomum (Cuvier). Aquacult. Res. 26: 901-909.

Moriarty, C.M. \& D.W.J. Moriarty. 1973. Quantitative estimation of the daily ingestion of phytoplankton by Tilapia nilotica and Haplochromis nigripinnis in lake George, Uganda. Proc. Zool. Soc. Lond. 171: 15-23.

Nose, T. 1966. Recent advances in the study of fish digestion in Japan. Symposium on Finfish Nutrition and Fish Feed Technology, European Inland Fisheries Advisory Commission/FAO, Belgrade, Serbia.

N.R.C. National Research Council. 1993. Nutrient requirements of fish. National Academic, Washington D.C., USA.

Okada, E.K., A.A. Agostinho \& L.C. Gomes. 2005. Spatial and temporal gradients in artisanal fisheries of a large Neotropical reservoir, the Itaipu Reservoir, Brazil. Canadian Journal of Fisheries and Aquatic Sciences. 62: 714-724.

Oliveira-Filho, P.R.C. \& D.M. Fracalossi. 2006. Coeficientes de digestibilidade aparente de ingredientes para juvenis de jundiá. Rev. Bras. Zootec. 35: 1581-1587.

Silva, D.J. \& A.C. Queiroz. 2002. Análise de Alimentos: métodos químicos e biológicos. Universidade Federal de Viçosa, Viçosa, Brasil.
Silva, G.C., N.S. Hahn, E. Gubiani \& R. Fugi. 2005. Composição da dieta de Pterodoras granulosus (Valenciennes, 1821) após o estabelecimento dos moluscos invasores na planície de inundação do alto rio Paraná, PR/MS. Exame Geral de Qualificação. Universidade Estadual de Maringá, Maringá, Brasil.

Silva, J.A.M., M. Pereira-Filho \& M.I. Oliveira-Pereira. 2000. Seasonal variation of nutrients and energy in tambaqui's (Colossoma macropomum CUVIER, 1818) natural food. Rev. Bras. Biol. 60: 599-605.

Silva, J.A.M., M. Pereira-Filho \& M.I. Oliveira-Pereira. 2003. Frutos e sementes consumidos pelo tambaqui, Colossoma macrompum (Cuvier, 1818) incorporados em rações. Digestibilidade e velocidade de trânsito pelo trato gastrointestinal. Rev. Bras. Zootec. 32: 1815-1824.

Smith, R.R. 1978. Method for determination of digestibility and metabolizable energy of feedstuffs for finfish, p. 453-459. In J.E. Halver \& K. Thiews (eds.). Proceedings of the World Symposium on Finfish Nutrition and Fish Feed Technology. Heenemann, Berlin, Germany.

Thomas, C.J. \& L.B. Cahoon. 1993. Stable isotope analyses differentiate between different trophic pathways supporting rocky-reef fishes. Mar. Ecol. Progr. 95: 19-24.

Vidal, M.V., J.L. Donzele, D.R. Andrade \& L.C. Santos. 2004. Determinação da digestibilidade da matéria seca e da proteína bruta do fubá de milho e do farelo de soja para tambaqui (Colossoma macropomum), utilizando-se técnicas com uso de indicadores internos e externos. Rev. Bras. Zootec. 33: 2193-2200.

Winemiller, K.O. 1989. Ontogenetic diet shifts and resource partitioning among piscivorous fishes in the Venezuelan llanos. Environ. Biol. Fishes 26: 177-199.

Yossa, M.I. 2002. Estratégia alimentar de peixes detritívoros das bacias do Orinoco e do Amazonas. INPA, 2002. Ph. D. Thesis, Universidade do Amazonas, Manaus, Amazônia, Brasil.

Yossa, M.I. \& C.A.R.M. Araújo-Lima. 1998. Detritivory in two amazonian fish species. J. Fish Biol. 52: 1141-1153. 